Pediat. Res. 6: 649-658 (1972)

Gysteine

cystine

cystinosis glutathione-cystine transhydrogenase leukocyte

lysosome

\title{
Enzymic Reduction of Cystine by Subcellular Fractions of Cultured and Peripheral Leukoyctes from Normal and Cystinotic Individuals
}

\author{
F. Tietze ${ }^{[46]}$, K. H. Bradley, and J. D. Sahulman \\ National Institute of Arthritis and Metabolic Diseases, National Institutes of Health, Bethesda, Maryland, USA
}

\section{Extract}

Lysates of cultured and freshly drawn isolated peripheral leukocytes from normal and cystinotic individuals were examined for cystine-reducing activity, with particular emphasis on possible enzyme action in lysosome-containing fractions. Whole cell extracts of cultured leukocytes were found to possess strong glutathione-cystine transhydrogenase activity at both $\mathrm{pH} 7.5$ and 5.5; no significant difference in this enzyme activity between extracts of normal and cystinotic cells was observable at either pH. Subcellular fractionation of these cultured leukocytes indicated that the major portion of transhydrogenase activity in the $5.5-7.5 \mathrm{pH}$ range was confined to the highspeed supernatant (cytoplasmic) fraction, with little or no activity being detectable in the granular fractions. Comparative enzyme assays at both $\mathrm{pH} 4.5$ and 7.5 with lysosomal and supernatant fractions of peripheral leukocytes freshly drawn from normal and cystinotic donors were consistent with the foregoing results in terms of the subcellular distribution of glutathione-cystine transhydrogenase activity; again there appeared to be no significant difference in the transhydrogenase activities of these fractions from normal and cystinotic leukocytes at either pH. The relation of these observations to the pathogenesis of cystinosis is discussed.

\section{Speculation}

Analogy with other lysosomal storage diseases suggests that the intralysosomal compartmentalization of cystine in cells of cystinotic individuals may be the result of an impaired mechanism of degradation of the amino acid within this cellular organelle. To date, however, convincing evidence to support this view is lacking. Alternative explanations implicating a defective membrane system associated with the egress of cystine from the lysosome, while equally plausible, likewise have yet to be confirmed experimentally; studies of subcellular transport of cystine in cystinosis are needed, but technical problems will make such investigations quite difficult.

\section{Introduction}

Human cystinosis is an inheritable disorder characterized by an excessive accumulation of cystine primarily within cells of the reticulo-endothelial system [2, 24].
Although it has been reasonable to suppose that this accumulation may reflect a derangement in the degradative metabolism of the amino acid, attempts to localize an enzyme defect in the catabolic pathway have not been successful $[8,11,24]$. Early reports $[9,25,32]$ 
implicating the putative initial step in this sequence, viz., enzymic reduction to cysteine, have not been supported in subsequent studies [11,24]. However, a number of recent findings have served to focus continued attention on the reductive aspect of cystine metabolism in relation to cystinosis and to stimulate its further investigation along the lines described in this paper. These are, principally, recognition of the storage of cystine within isolated cells [14, 16] of afflicted individuals in an apparently intralysosomal location $[6,12$, $20,22,31]$ and the reported presence of glutathionecystine transhydrogenase activity in the lysosomal fraction of at least one normal mammalian tissue [26]. These findings have suggested the desirability of extending previous studies of the enzymic reduction of cystine in normal and cystinotic cells to the more acidic $\mathrm{pH}$ 's generally characteristic of lysosomal activity. Since previous studies have indicated that the high-speed supernatant fraction of various animal tissues also contains a reduced glutathione (GSH)-cystine (CySSCy) transhydrogenase activity [26, 27, 30], it also seemed important to examine in addition the subcellular fractions of normal and cystinotic cells with respect to cystine reduction at acidic and neutral $\mathrm{pH}$ 's in order to avoid a possible "masking" of lysosomal activity by an analogous but distinct supernatant enzyme.

It was previously demonstrated that freshly drawn peripheral [14, 21, 24] or cultured [19] leukocytes derived from blood of cystinotic individuals are characterized by abnormal intracellular accumulations of cystine, apparently within the lysosomal granules of these cells [20]. Obviously, such cells constitute a convenient and useful source of material for biochemical investigations into the nature of this disease. In the present investigation, extracts of cultured or freshly drawn peripheral leukocytes from normal and cystinotic individuals have been fractionated into a variety of granular and supernatant components and subsequently assayed for disulfide-reducing activities at both neutral and acidic pH's. The comparative results obtained in these and related experiments are reported in this paper.

\section{Materials and Methods}

\section{Materials}

L-Cystine [33], $\beta, \beta^{\prime}$-hydroxyethyl disulfide [34], yeast glutathione reductase (about $100 \mathrm{IU} / \mathrm{mg}$ ) [35], D-cystine [35], reduced nucleotides [35], glutathione [35], bovine zinc insulin [36], and Triton X-100 [37] were obtained commercially. Bovine zinc insulin was dialyzed against $5 \mathrm{~mm} \mathrm{HCl}$, and the protein was then recovered by lyophilization.

\section{Preparation of Leukocyte Fractions}

Leukocytes were obtained from normal adult blood and from the blood of three cystinotic siblings 3- to 6 -years-old. Some experiments were also performed with extracts of leukocytes obtained from the mother of these children.

Three different procedures were employed for the preparation of leukocyte fractions from normal and cystinotic individuals. These were as follows.

1. Batch preparation of normal human leukocyte lysosomes. Five to 30 units of human buffy coat [43] were mixed with an equal volume of $4 \%$ dextran [36] in $0.9 \%$ saline, and the erythrocytes were allowed to sediment for $1 \mathrm{hr}$. The overlying suspension was collected, the leukocytes were concentrated by centrifugation, and the residual erythrocytes were lysed by hypotonic treatment $[14,15]$. The leukocytes were then washed once by suspension and centrifuged in $20 \mathrm{ml}$ $0.25 \mathrm{M}$ sucrose, with or without $1 \mathrm{mM}$ EDTA ( $\mathrm{pH} 7.0$ ), and resuspended in $30-40 \mathrm{ml}$ sucrose solution. For preparation of whole cell extracts, a small portion of the washed cells was subjected to 5-10 cycles of freezethaw treatment in dry ice-ethanol mixture and the resulting suspension was used without further treatment. The remaining cells were sonicated [14] in $2 \mathrm{ml}$ batches and centrifuged at $600 \times g$ for $10 \mathrm{~min}$ to remove unbroken cells and nuclei. Supernatants were combined and centrifuged at $4000 \times g$ for $10 \mathrm{~min}$ to yield a light green, dense pellet representing the "lysosomal" fraction [23]; the pellet was taken up in $20 \%$ sucrose (with or without EDTA) and, after a second centrifugation for $10 \mathrm{~min}$ at $4000 \times \mathrm{g}$, was subjected to 10 freeze-thaw cycles as above. Supernatant fractions decanted from the $4000 \times g$ centrifugations were combined and centrifuged at $100,000 \times g$ for $30-60 \mathrm{~min}$ $[38,39]$. A clear supernatant solution and a residual mitochondrial-microsomal pellet were obtained.

2. Leukocyte fractions from cultured cells. Leukocytes from normal and cystinotic humans were grown in continuous culture by a modification [19] of the technique of Gerber and Monroe [5]. After suitable growth, cells were collected by centrifugation at $400 \times$ $g$ and washed once in $0.9 \%$ saline. For preparation of whole cell extracts, washed cells were taken up in a small volume of saline or $0.25 \mathrm{~m}$ sucrose and ruptured by freeze-thaw treatment as above. For subcellular frac- 
tionation, washed cells were suspended in $0.25 \mathrm{~m} \mathrm{su}-$ crose and sonicated as in procedure 1. After separation of nuclei and residual intact cells by centrifugation at $600 \times \mathrm{g}$ for $10 \mathrm{~min}$, the combined supernatants were layered over $1.5 \mathrm{ml} 20 \%$ sucrose and centrifuged for 10 $\min$ at $27,000 \times g$ [40]. The resulting pellet is the mitochondrial-lysosomal fraction, and the supernatant contained in the less dense sucrose layer is the microsomal-supernatant fraction.

In other variations of this procedure the post-nuclear supernatants were spun at $100,000 \times g$ for $I \mathrm{hr}$. The pellet contained a layer of opaque particles typical of the 10-min 27,000 $\times g$ particles over which was a tightly packed gelatinous layer characteristic of microsomes. The fractions obtained in this procedure are the supernatant and the mitochondrial-lysosomal-microsomal fractions. Disruption of the particles in the latter fraction was accomplished by the freeze-thaw treatment described above after suspension of the pellet in sucrose solution.

3. Leukocyte fractions from peripheral blood of normal and cystinotic individuals. Leukocytes were obtained from the buffy coat layer of freshly drawn heparinized blood $(50-100 \mathrm{ml})$ in a manner similar to procedure 1. Extracts of whole cells were prepared by multiple freeze-thaw treatment. To prepare subcellular fractions, sonicates of washed cells were centrifuged at $600 \times g$ for $10 \mathrm{~min}$ and the resulting supernatant fractions were layered over $1 \mathrm{ml} 20 \%$ sucrose and centrifuged at $8000 \times g$ for $10 \mathrm{~min}$ [40]. The pellet (mitochondrial-lysosomal fraction) was taken up in $0.25 \mathrm{M}$ sucrose and disrupted by freeze-thaw treatment, while the microsomal-supernatant fraction was recovered from the less dense upper layer.

\section{Cystine Content of Cultured Cystinotic and Normal Cells}

Cystine levels of our cultured cells, determined as described previously [19], ranged from 0.3 to 1.4 $\mu$ moles half-cystine/g cell protein. Although these values are somewhat lower than those reported in a recent study [19] for the same cell lines grown in continuous culture, they nevertheless represent, at the minimum, a 10- to 60 -fold excess relative to the corresponding levels in our control cells $(\leqslant 0.024 \mu$ moles half-cystine/g protein). The intracellular cystine levels in leukocytes of freshly drawn blood of the normal and cystinotic individuals were not determined in this investigation; however, on the basis of previous assays [14], it could be anticipated that the cystinotic cells would exhibit cystine levels in the range of 4-14 $\mu$ moles halfcystine/g protein.

\section{Measurement of GSH-CySSCy Transhydrogenase Ac- tivity}

Activity of GSH-disulfide transhydrogenase was measured in the $5.5-7.5 \mathrm{pH}$ range by a spectrophotometric procedure [27]. Briefly, the method consists of simultaneous coupling of oxidized glutathione (GSSG) formation, arising from enzyme-catalyzed reduction of cystine or other disulfide substrate by GSH, to oxidation of NADPH in the presence of exogenous yeast glutathione reductase. Reaction mixtures contained, in a total volume of $1.0 \mathrm{ml}, 0.2 \mu$ mole NADPH, $10 \mu \mathrm{g}$ yeast glutathione reductase, $0.25 \mu$ mole L-cystine, GSH, and cell extract. Differential measurement of NADPH utilization at $25^{\circ}$ was carried out at $340 \mathrm{~m} \mu$ [4I] with a "balanced" system consisting of reference and test cuvettes containing identical quantities of all components except for the disulfide substrate, which was present in test cuvettes only. This arrangement served to compensate for spurious oxidation of GSH or NADPH by crude tissue extract, as well as to permit use of relatively turbid reaction mixtures possessing initially high intrinsic absorbancies. In order to compensate for the slower rates of reduction at lower $\mathrm{pH}$, it was necessary to adjust arbitrarily the concentration of GSH in accordance with the specific $\mathrm{pH}$ under study. At $\mathrm{pH} 7.5$, the mixture contained $0.1 \mathrm{M}$ Tris -5 mM EDTA and 0.1-0.25 mM GSH; at pH 6.5, $0.1 \mathrm{~m}$ phosphate-1 mM EDTA and 0.5-2.5 mM GSH; and at $\mathrm{pH} 5.5,0.1 \mathrm{~m}$ citrate-1 mM EDTA and $10 \mathrm{~mm}$ GSH. Measurements of transhydrogenase activity were always corrected for the basal or 'non-enzymic' rate of reduction of disulfide by GSH which took place in identical reaction mixtures lacking the transhydrogenase component. Results are expressed in units of activity corresponding to the initial change in absorbancy at $340 \mathrm{~m}_{\mu}$ per 4 min period; specific activity is defined as units/mg protein.

Due to the inactivity of the glutathione reductase system below $\mathrm{pH} 5$, it was not possible to employ the continuously coupled system for measurement of transhydrogenase activity at a more acidic $\mathrm{pH}$. For measurement at $\mathrm{pH} 4.5$, therefore, a new assay technique was developed. Reaction mixtures consisting of $10 \mathrm{~mm}$ GSH, $0.5 \mathrm{~mm}$ L-CySSCy, and cell extract were allowed to incubate separately for $2 \mathrm{hr}$ at $25^{\circ}$ in $0.2 \mathrm{M}$ acetate - I mm EDTA buffer, $\mathrm{pH} 4.5$. As before, these incubation mixtures were made up in pairs identical in con- 

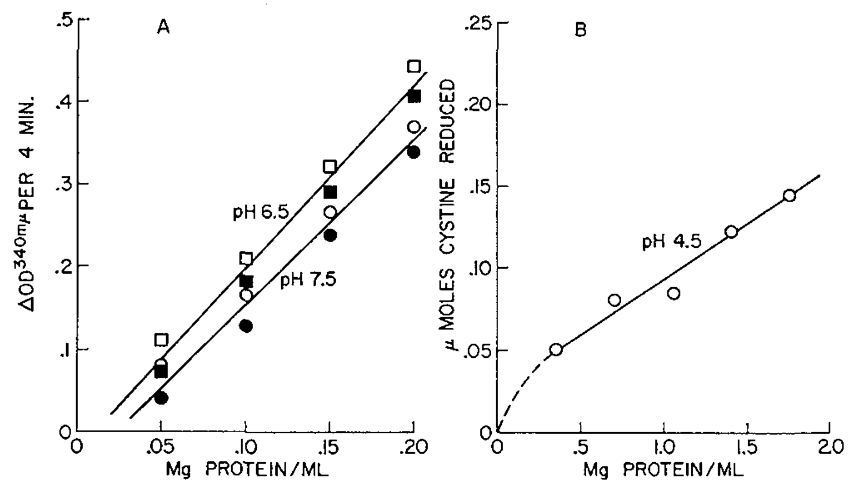

Fig. 1. Dependence of enzyme-catalyzed reduced glutathione (GHS)-cystine interchange on leukocyte protein concentration at $\mathrm{pH} 7.5,6.5$, and 4.5. Data shown have been corrected in all cases for the non-enzymic (spontaneous) interchange reactions. $A$. Spectrophotometric assay of interchange reactions at $\mathrm{pH} 7.5$ $(\mathrm{O}, \bullet)$ and $\mathrm{pH} 6.5$ ( $\square, \boldsymbol{\square})$. Standard reaction mixtures (open symbols) contained, per ml, $0.2 \mu$ mole NADPH, $10 \mu \mathrm{g}$ yeast glutathione reductase, $0.25 \mu$ mole L-cystine, leukocyte extract, and $0.25 \mu$ mole ( $\mathrm{pH} 7.5$ ) or $2.5 \mu$ mole ( $\mathrm{pH} 6.5$ ) GSH. Cuvettes were balanced with respect to all components except the disulfide substrate. Filled symbols represent corresponding reaction rates with assay mixtures containing an additional $10 \%$ cystine (i.e., 0.025 $\mu$ mole) added to both cuvettes in order to simulate the possible effect of endogenous cystine on the observed reaction rate. For further discussion see the text. $B$. Enzyme catalyzed interchange at $\mathrm{pH}$ 4.5. Reaction mixtures, $1.0 \mathrm{mI}$, contained $0.5 \mu$ mole $\mathrm{L}$ cystine, leukocyte extract, and $10 \mu$ moles GSH. Mixtures were incubated for $2 \mathrm{hr}$ at $25^{\circ}$ and then assayed for GSSG.

tent except for the absence of cystine from one of the mixtures in order to compensate for any irrelevant oxidation of GSH. At given time intervals, aliquots of the paired mixtures were brought rapidly to $0^{\circ}$ and centrifuged for $10 \mathrm{~min}$ at $10,000 \times g$. The clear supernatants were added to paired cuvettes containing 0.2 $\mu$ mole NADPH and $10 \mu \mathrm{g}$ yeast glutathione reductase in phosphate-EDTA buffer, $\mathrm{pH}$ 6.5, and the differential absorbancy at $340 \mathrm{~m}_{\mu}$ was determined immediately as a measure of excess GSSG formation. Similar measurements were carried out concurrently with paired reaction mixtures lacking cell extract in order to correct for the spontaneous interchange of GSH and cystine at $\mathrm{pH} 4.5$. Specific enzyme activities at $\mathrm{pH} 4.5$ were expressed as $\mu$ mole cystine reduced per milligram protein during $2 \mathrm{hr}$.

Data represented by open symbols in Figure 1 indicate that under the standard conditions of $\mathrm{pH}$ and reagent concentrations outlined above, the transhydrogenase-catalyzed reaction, after correction for the "basal" reduction of substrate, displayed a rectilinear dependence on leukocyte enzyme concentration within the limits shown. Although the corresponding data at
$\mathrm{pH} 5.5$ were not obtained in this particular series of assays, other experiments of a similar nature, carried out with an extract of rat liver, demonstrated an analogous dependence of enzyme activity with protein concentration at this $\mathrm{pH}$.

It is important to note, in connection with the assay systems employed here, that the amount of free endogenous cystine contributed to the reaction mixture by extracts derived from the cultured cystinotic cells ( $\leqslant 0.7$ nanomoles cystine/mg protein) was always negligible in comparison with the quantity of exogenous cystine (250 or 500 nanomoles) routinely added to these mixtures. This remained true, although to a lesser degree, for those assays involving cellular extracts of leukocytes freshly drawn from cystinotic subjects, the granular fractions of which might be expected to contain relatively large amounts of sequestered cystine; even here, however, the quantity of endogenous free disulfide was unlikely to have exceeded $10 \%$ of the exogenous cystine at most. On this basis, it seems highly improbable that the measured enzyme activities asssociated with the various cellular preparations of cystinotic and normal leukocytes utilized in this investigation were influenced to any appreciable degree by the endogenous cystine contents. Data to support this contention is shown in the spectrophotometric assays represented by the closed symbols of Figure 1A, in which an additional quantity of cystine $(0.025 \mu$ mole $)$ over and above that routinely present in the standard reaction mixtures (viz., $0.25 \mu$ mole) was incorporated in both cuvettes of the assay systems so as to simulate the effect of endogenous free cystine in the leukocyte extracts; it is evident from these data that, in comparison with the corresponding data of the standard control assays (Fig. 1A, open symbols), this additional $10 \%$ excess of cystine, which as noted above would be expected to represent an upper limit for endogenous cystine in leukocyte extracts, had little noticeable effect on the rate of the enzyme-catalyzed reaction.

Protein concentrations were calculated according to the equation of Layne [7] from absorbancies at 260 and $280 \mathrm{~m}_{\mu}$ of cell extracts diluted with $0.25 \%$ sodium deoxycholate.

\section{Results}

GSH-Cystine Transhydrogenase Activities in Normal and Cystinotic Leukocytes

Preliminary to a detailed comparison of the cystinereducing capacities of normal and cystinotic leuko- 


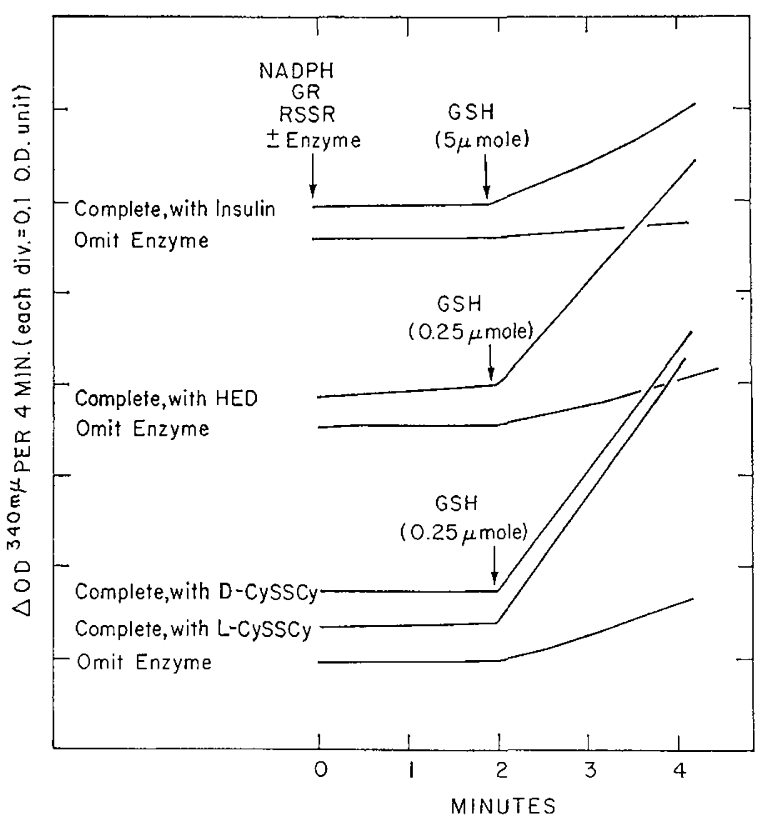

Fig. 2. Reduced glutathione (GSH)-disulfide transhydrogenase activity of whole cell extracts of cultured normal leukocytes at pH 7.5. Reaction mixtures were made up in $1.0 \mathrm{ml}$ Tris-EDTA, $\mathrm{pH} 7.5$, and contained initially $0.2 \mu$ mole NADPH, $10 \mu \mathrm{g}$ yeast glutathione reductase (GR), $0.18 \mathrm{mg}$ leukocyte protein, and disulfide substrates (RSSR) as follows: $\beta, \beta^{\prime}$-hydroxyethyl disulfide (HED) and insulin, $1 \mu$ mole -SS-; $D$ - and L-cystine (CySSCy), $0.25 \mu$ mole. GSH was added in the amounts indicated after 2 min (second vertical arrow). Cuvettes were balanced with respect to all components except the disulfide substrate. The lowest curve of each set of reactions (labeled Omit Enzyme) represents the basal rate of NADPH oxidation in identical mixtures lacking leukocyte extract. The vertical displacement of the spectrophotometric tracings is for display purposes only and does not signify absolute differences in initial absorbancy of the reaction mixtures.

cytes, it was desirable to determine whether extracts of normal cells could reduce cystine by mechanisms which had previously been found to be present in rat liver at neutral $\mathrm{pH}$ [27]. Although little or no nucleotide-dependent reductase activity was found in extracts of cultured normal leukocytes, in contrast to the previous finding with rat liver, strong GSH-disulfide transhydrogenase activity was apparent (Fig. 2). As is depicted in Figure 2, addition of GSH to reaction mixtures containing NADPH, yeast glutathione reductase, and cystine or other disulfide substrate leads to rapid oxidation of reduced nucleotide at rates considerably greater than the basal rates (labeled "omit enzyme" in the figure) which occurred in the absence of cell extract. These activities are comparable to those which were observed previously with rat liver and indicated that normal leukocytes contain one or more transhy- drogenase-like enzymes which can participate in disulfide reduction. It is evident from Figure 2 that the $\mathrm{D}$ and L-forms of cystine are reduced at essentially equal rates by these extracts; similar findings were previously made with the rat liver system [27]. In addition, as in the case of liver, transhydrogenase activity in leukocytes is exhibited toward both protein and nonprotein disulfide substrates.

The coupled system employed to demonstrate GSHcystine transhydrogenase activity at $\mathrm{pH} 7.5$ (Fig. 2) could be used with only minor modification at $\mathrm{pH}$ 's down to 5.5, provided the concentration of GSH was increased accordingly. Below this $\mathrm{pH}$, however, it was necessary to employ a modified procedure (see Methods) in which the GSH-CySSCy interchange at $\mathrm{pH} 4.5$ was followed by a subsequent GSSG assay at $\mathrm{pH} 6.5$.

Table I. Reduced glutathione (GSH)-cystine transhydrogenase activities of whole cell extracts of cultured leukocytes derived

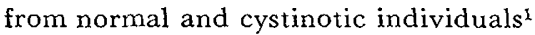

\begin{tabular}{|c|c|c|c|c|c|c|}
\hline $\begin{array}{l}\text { Ex- } \\
\text { peri- } \\
\text { ment }\end{array}$ & Donor & Cell line & $\begin{array}{c}\text { Protein, } \\
\text { mg }\end{array}$ & $\mathrm{pH}$ & $\underset{\mathrm{mM}}{\mathrm{GSH},}$ & $\begin{array}{l}\text { Specific } \\
\text { activity, } \\
\Delta 0 . D . / 4 \\
\mathrm{~min} / \mathrm{mg}\end{array}$ \\
\hline \multirow[t]{4}{*}{1} & $G$ & normal & 0.25 & 7.5 & 0.25 & 1.12 \\
\hline & $S$ & normal & 0.26 & & & 0.76 \\
\hline & $L M$ & cystinotic & 0.37 & & & 0.54 \\
\hline & $I M$ & cystinotic & 0.29 & & & 0.64 \\
\hline \multirow[t]{7}{*}{2} & $G$ & normal & 0.41 & 7.5 & 0.25 & 0.78 \\
\hline & $S$ & normal & 0.34 & & & 0.46 \\
\hline & $E$ & normal & 0.45 & & & 0.63 \\
\hline & $R M^{2}$ & heterozygous & 0.26 & & & 0.90 \\
\hline & $I M$ & cystinotic & 0.36 & & & 0.75 \\
\hline & $L M$ & cystinotic & 0.26 & & & 0.83 \\
\hline & $T M$ & cystinotic & 0.35 & & & 0.48 \\
\hline \multirow[t]{4}{*}{3} & $G$ & normal & 0.25 & 5.5 & 10 & 0.44 \\
\hline & $S$ & normal & 0.26 & & & 0.33 \\
\hline & $L M$ & cystinotic & 0.37 & & & 0.24 \\
\hline & $I M$ & cystinotic & 0.20 & & & 0.28 \\
\hline \multirow[t]{7}{*}{4} & $G$ & normal & 0.41 & 5.5 & 10 & 0.38 \\
\hline & $S$ & normal & 0.34 & & & 0.23 \\
\hline & $E$ & normal & 0.45 & & & 0.31 \\
\hline & $R M^{2}$ & heterozygous & 0.26 & & & 0.51 \\
\hline & $I M$ & cystinotic & 0.36 & & & 0.42 \\
\hline & $L M$ & cystinotic & 0.26 & & & 0.44 \\
\hline & $T M$ & cystinotic & 0.35 & & & 0.26 \\
\hline
\end{tabular}

1 Reaction mixtures $(1.0 \mathrm{ml})$ contained $0.2 \mu$ mole NADPH, $10 \mu \mathrm{g}$ yeast glutathione reductase, and $0.25 \mu$ mole cystine. $\mathrm{Cu}-$ vettes were balanced with respect to all components except disulfide substrate. Enzyme measurements at $340 \mathrm{~m} \mu$ were carried out at $25^{\circ}$ in the continuously coupled spectrophotometric system (see Methods). All activities have been corrected for the basal reduction of cystine.

2 Mother of cystinotic patients. 
Initial studies on the comparative GSH-CySSCy transhydrogenase activities of normal and cystinotic leukocytes were carried out at $\mathrm{pH} 7.5$ and 5.5 with whole extracts of cultured cells. These results (Table I) failed to demonstrate any consistent differences in the levels of this enzyme at either $\mathrm{pH}$ in cells derived from normal subjects and from individuals homozygous for cystinosis. Experiments 2 and 4 of Table I also include the results of enzyme assays on cultured cells derived from the mother of the cystinotic patients and are therefore presumed to represent the level of enzyme activity characteristic of the heterozygous state; no significant difference in enzyme content could be noted in these extracts.

Further enzyme assays in the $7.5-5.5 \mathrm{pH}$ range were carried out with various particulate and supernatant fractions prepared from these perpetual cell lines (Table II). In all cases, the transhydrogenase activity exhibited by the particulate fractions was only a small percent of that observed in the corresponding supernatant fraction. As in Table $\mathrm{I}$, no striking or consistent difference in specific enzyme activity between normal and cystinotic fractions was evident in this series of experiments.
Owing to limitations imposed by the quantities of cellular material available from leukocytes grown in culture, it was not feasible to extend the data of Table II to the individual components of the mixed mitochondrial-lysosomal fraction. In order to study this aspect further, supernatant and lysosomal fractions of normal human leukocytes were prepared on a relatively large scale from blood bank buffy coat and their transhydrogenase activities at $\mathrm{pH} 7.5$ and 4.5 were compared. Results of these assays are shown in Table III. It is again evident that GSH-CySSCy transhydrogenase activity of the lysosomal fraction was negligible in comparison with the activity exhibited by the supernatant fraction at either $\mathrm{pH}$. Inclusion of $0.1 \%$ Triton $\mathrm{X}-100$ in the reaction mixtures in one experiment (experiment 4) did not increase lysosomal activity significantly beyond the level noted in its absence. To rule out a possible inhibitory effect of EDTA on lysosomal transhydrogenase activity, two experiments (experiments 5 and 6 ) were carried out with supernatant and lysosomal fractions prepared and assayed in its absence; no improvement in enzyme activity was noted under these conditions.

A final series of experiments on extracts of normal

Table II. Comparative reduced glutathione (GSH)-cystine transhydrogenase activities of subcellular fractions of cultured leukocytes derived from normal and cystinotic individuals ${ }^{1}$

\begin{tabular}{|c|c|c|c|c|c|c|c|}
\hline Experiment & Donor & Cell line & Cell fraction ${ }^{2}$ & Protein, $\mathrm{mg}$ & $\mathrm{pH}$ & GSH, mM & $\begin{array}{c}\text { Specific activity } \\
\Delta O . D . / 4 \mathrm{~min} / \mathrm{mg}\end{array}$ \\
\hline 1 & $\begin{array}{l}G \\
T M \\
G \\
T M\end{array}$ & $\begin{array}{l}\text { normal } \\
\text { cystinotic } \\
\text { normal } \\
\text { cystinotic }\end{array}$ & $\begin{array}{l}\text { S } \\
\text { S } \\
\text { Mit-Lys-Mic } \\
\text { Mit-Lys-Mic }\end{array}$ & $\begin{array}{l}0.21 \\
0.17 \\
0.83 \\
0.62\end{array}$ & 7.5 & 0.25 & $\begin{array}{l}0.70 \\
0.70 \\
0.025 \\
0.044\end{array}$ \\
\hline 2 & $\begin{array}{l}C S \\
L M \\
C S \\
L M\end{array}$ & $\begin{array}{l}\text { normal } \\
\text { cystinotic } \\
\text { normal } \\
\text { cystinotic }\end{array}$ & $\begin{array}{l}\text { S-Mic } \\
\text { S-Mic } \\
\text { Mit-Lys } \\
\text { Mit-Lys }\end{array}$ & $\begin{array}{l}0.65 \\
0.27 \\
0.55 \\
0.26\end{array}$ & 7.5 & 0.25 & $\begin{array}{l}0.27 \\
0.46 \\
0.02 \\
0.07\end{array}$ \\
\hline 3 & $\begin{array}{l}C S \\
L M \\
C S \\
L M\end{array}$ & $\begin{array}{l}\text { normal } \\
\text { cystinotic } \\
\text { normal } \\
\text { cystinotic }\end{array}$ & $\begin{array}{l}\text { S-Mic } \\
\text { S-Mic } \\
\text { Mit-Lys } \\
\text { Mit-Lys }\end{array}$ & $\begin{array}{l}0.65 \\
0.27 \\
1.09 \\
0.52\end{array}$ & 6.5 & 1.0 & $\begin{array}{l}0.11 \\
0.20 \\
0.02 \\
0.05\end{array}$ \\
\hline 4 & $\begin{array}{l}C S \\
L M\end{array}$ & $\begin{array}{l}\text { normal } \\
\text { cystinotic }\end{array}$ & $\begin{array}{l}\text { S-Mic } \\
\text { S-Mic }\end{array}$ & $\begin{array}{l}0.65 \\
0.27\end{array}$ & 6.5 & 2.5 & $\begin{array}{l}0.27 \\
0.52\end{array}$ \\
\hline 5 & $\begin{array}{l}C \\
T M \\
C \\
T M\end{array}$ & $\begin{array}{l}\text { normal } \\
\text { cystinotic } \\
\text { normal } \\
\text { cystinotic }\end{array}$ & $\begin{array}{l}\text { S-Mic } \\
\text { S-Mic } \\
\text { Mit-Lys } \\
\text { Mit-Lys }\end{array}$ & $\begin{array}{l}0.26 \\
0.38 \\
0.45 \\
0.61\end{array}$ & 6.5 & 2.5 & $\begin{array}{l}0.38 \\
0.52 \\
0.096 \\
0.093\end{array}$ \\
\hline 6 & $\begin{array}{l}G \\
T M \\
G \\
T M\end{array}$ & $\begin{array}{l}\text { normal } \\
\text { cystinotic } \\
\text { normal } \\
\text { cystinotic }\end{array}$ & $\begin{array}{l}\text { S } \\
\text { S } \\
\text { Mit-Lys-Mic } \\
\text { Mit-Lys-Mic }\end{array}$ & $\begin{array}{l}0.21 \\
0.17 \\
0.83 \\
0.62\end{array}$ & 5.5 & 10 & $\begin{array}{l}0.29 \\
0.32 \\
0.020 \\
0.029\end{array}$ \\
\hline
\end{tabular}

1 Enzyme activities are corrected for spontaneous reduction of cystine. See Methods for preparation of cell fractions.

$2 \mathrm{~S}$ : high-speed supernatant, Mic : microsomal, Mit : mitochondrial, Lys : lysosomal. 
and cystinotic leukocytes employed cells obtained from freshly drawn peripheral blood. The results (Table IV) showed that little or no transhydrogenase activity was present in the mitochondrial-lysosomal fraction at pH 7.5 as compared with the supernatant fraction. No significant or consistent difference in the level of transhydrogenase activity between cystinotic and normal whole cells or supernatant fractions at $\mathrm{pH} 4.5$ or 7.5 was noted.

\section{Discussion}

Several enzyme mechanisms for reduction of cystine or other disulfides have been described. These include nucleotide-dependent reductase and GSH-disulfide transhydrogenase activities (reactions 1 and 2, respectively). In rat liver supernatant fraction, the latter activity has been demonstrated $[27,28]$ to be capable of coupling with the endogenous glutathione reductase system (reaction 3) also present in the supernatant fraction, which functions to drive the interchange reaction by virtue of the continual regeneration of $\mathrm{GSH}$ from GSSG.

$$
\begin{aligned}
& \text { 2NAD }(\mathrm{P}) \mathrm{H}+\mathrm{CySSCy} \rightarrow 2 \mathrm{NAD}(\mathrm{P})+2 \mathrm{CySH} \\
& \mathrm{GSH}+\mathrm{CySSCy} \rightleftharpoons \mathrm{CySSG}+\mathrm{CySH} \\
& \mathrm{GSH}+\mathrm{CySSG} \rightleftharpoons \mathrm{GSSG}+\mathrm{CySH} \\
& 2 \mathrm{NADPH}+\mathrm{GSSG} \frac{\text { glutathione }}{\text { reductase }} 2 \mathrm{NADP}+2 \mathrm{GSH}
\end{aligned}
$$

In this investigation, nucleotide-dependent CySSCy reductase activity (reaction 1) was found to be virtually undetectable in extracts of normal cultured or peripheral leukocytes under a wide variety of conditions, thus precluding any comparative assessment of this activity in normal and cystinotic cells. This observation stands in marked contrast to the situation in rat liver, where strong NADPH-dependent (but not NADH-dependent) reductase activity had previously been found in the high-speed supernatant fraction [27]. An undefined NADH-dependent cystine reductase of low activity was previously measured in extracts of normal and cystinotic liver by Patrick [11]; no difference in the level of this activity in these tissues could be observed.

A high glutathione reductase activity was apparent in leukocyte extracts. The activity was specific for NADPH and, as in liver [13], appeared to be confined predominantly to the supernatant fraction. No evidence was obtained for the presence of significant activity at a $\mathrm{pH}(5-6)$ which might be presumed to be characteristic of lysosomal activity. In agreement with

\begin{tabular}{|c|c|c|c|c|c|}
\hline$\underset{\text { ment }}{\text { Experi- }}$ & $\mathrm{pH}$ & GSH, mM & $\begin{array}{c}\text { Cell } \\
\text { fraction }\end{array}$ & $\begin{array}{l}\text { Protein, } \\
\text { mg }\end{array}$ & $\begin{array}{l}\text { Specific } \\
\text { activity }\end{array}$ \\
\hline \multirow[t]{4}{*}{1} & 7.5 & 0.25 & $\mathrm{~S}$ & 0.16 & 1.9 \\
\hline & & & S & 0.15 & 2.9 \\
\hline & & & Lys & 1.0 & 0.01 \\
\hline & & & Lys & 0.90 & 0.01 \\
\hline \multirow[t]{2}{*}{2} & 4.5 & 10 & $\mathrm{~S}$ & 0.19 & 0.64 \\
\hline & & & Lys & 3.6 & 0.006 \\
\hline \multirow[t]{2}{*}{3} & 4.5 & 10 & $\mathrm{~S}$ & 0.31 & 0.45 \\
\hline & & & Lys & 8.2 & 0.006 \\
\hline \multirow[t]{2}{*}{$4^{4}$} & 4.5 & 10 & $\mathrm{~S}$ & 0.31 & 0.47 \\
\hline & & & Lys & 8.2 & 0.013 \\
\hline \multirow[t]{3}{*}{$5^{5}$} & 7.5 & 0.25 & $S$ & 0.17 & 1.6 \\
\hline & & & Lys & 2.4 & 0.003 \\
\hline & & & Mit-Mic & 0.77 & 0.042 \\
\hline \multirow[t]{3}{*}{$6^{5}$} & 4.5 & 10 & $\mathrm{~S}$ & 0.33 & 0.29 \\
\hline & & & Lys & 2.4 & 0.0 \\
\hline & & & Mit-Mic & 1.5 & 0.006 \\
\hline
\end{tabular}

Table III. Comparative reduced glutathione (GSH)-cystine transhydrogenase activities of supernatant and lysosomal fractions of normal peripheral human leukocytes ${ }^{1}$

${ }^{1}$ Large-scale preparation of lysosomal and supernatant fractions of leukocytes obtained from blood bank buffy coat is described under Methods. Specific activities are corrected for spontaneous reduction of cystine.

2 S : high-speed supernatant, Mic: microsomal, Mit: mitochondrial, Lys : lysosomal.

${ }^{3}$ At $\mathrm{pH} 7.5, \Delta$ O.D. ${ }^{340 \mathrm{~m} \mu} / 4 \mathrm{~min} / \mathrm{mg}$ protein. At $\mathrm{pH} 4.5$, $\mu$ moles cystine reduced $/ 2 \mathrm{hr} / \mathrm{mg}$ protein.

${ }^{4}$ Interchange mixtures contained $0.1 \%$ Triton $\mathrm{X}-100$.

${ }^{5}$ Fractions prepared and assayed in absence of EDTA.

the results of Patrick [11], obtained with liver, no difference in glutathione reductase content could be noted in extracts of cystinotic and normal leukocytes at neutral $\mathrm{pH}$.

GSH-cystine transhydrogenase is the enzyme of greatest interest in these studies, both because of its high apparent activity in whole leukocyte extracts and because of its measurability over a wide $\mathrm{pH}$ range (4.5-7.5). It is of major importance that it was shown that the activity of this enzyme is always extremely low in the granular fraction of leukocytes, and that differences in the activity of these lysosome-containing fractions between cystinotic and normal cells could not be demonstrated. The enzyme appears to be localized predominantly, if not exclusively, in the supernatant fraction. The activity observed at $\mathrm{pH} 4.5$ probably represents merely the acidic limb of the $\mathrm{pH}$-activity curve for this cytoplasmic component. These results differ from those of States and Segal [26], who have reported the presence of GSH-cystine transhydrogenase activity in both the supernatant and lysosomal fractions of rat 
Table IV. Reduced glutathione (GSH)-cystine transhydrogenase activities of cell fractions prepared from peripheral leukocytes of normal and cystinotic individuals ${ }^{1}$

\begin{tabular}{|c|c|c|c|c|c|c|c|}
\hline Experiment & Donor & Cell type & Protein, mg & $\mathrm{pH}$ & GSH, mMr & Cell fraction ${ }^{2}$ & Specific activity ${ }^{3}$ \\
\hline \multirow[t]{8}{*}{1} & $E$ & normal & 0.77 & 4.5 & 10 & whole & 0.071 \\
\hline & $C S$ & normal & 1.23 & & & whole & 0.071 \\
\hline & $T M$ & cystinotic & 0.82 & & & whole & 0.078 \\
\hline & $I M$ & cystinotic & 0.64 & & & whole & 0.12 \\
\hline & $E$ & normal & 0.19 & 7.5 & 0.25 & whole & 0.21 \\
\hline & $C S$ & normal & 0.31 & & & whole & 0.26 \\
\hline & $T M$ & cystinotic & 0.10 & & & whole & 0.08 \\
\hline & $I M$ & cystinotic & 0.08 & & & whole & 0.51 \\
\hline \multirow[t]{6}{*}{2} & $B S$ & normal & 0.76 & 4.5 & 10 & S-Mic & 0.081 \\
\hline & $I M$ & cystinotic & 0.68 & & & S-Mic & 0.18 \\
\hline & $B S$ & normal & 1.52 & 7.5 & 0.1 & S-Mic & 0.034 \\
\hline & $I M$ & cystinotic & 0.68 & & & S-Mic & 0.22 \\
\hline & $B S$ & normal & 0.79 & & & Mit-Lys & 0.02 \\
\hline & $I M$ & cystinotic & 0.81 & & & Mit-Lys & 0.01 \\
\hline \multirow[t]{9}{*}{3} & $T B$ & normal & 0.98 & 4.5 & 10 & $\mathrm{~S}-\mathrm{Mic}$ & 0.050 \\
\hline & $L M$ & cystinotic & 0.81 & & & S-Mic & 0.095 \\
\hline & $I M$ & cystinotic & 1.10 & & & S-Mic & 0.12 \\
\hline & $T B$ & normal & 0.98 & 7.5 & 0.1 & S-Mic & 0.041 \\
\hline & $L M$ & cystinotic & 0.81 & & & S-Mic & 0.14 \\
\hline & $I M$ & cystinotic & 1.10 & & & S-Mic & 0.11 \\
\hline & $Y B$ & normal & 1.47 & & & Mit-Lys & 0.0 \\
\hline & $L M$ & cystinotic & 0.73 & & & Mit-Lys & 0.0 \\
\hline & $I M$ & cystinotic & 0.93 & & & Mit-Lys & 0.001 \\
\hline
\end{tabular}

${ }^{1}$ Cell fractions were prepared as described in Procedure 3 under Methods. Specific activities are corrected for spontaneous reduction of cystine.

${ }^{2} \mathrm{~S}$ : high-speed supernatant, Mic: microsomal, Mit: mitochondrial, Lys : lysosomal.

${ }^{3}$ At $\mathrm{pH} 7.5, \Delta \mathrm{O} . \mathrm{D} .340 \mathrm{~m} \mu / 4 \mathrm{~min} / \mathrm{mg}$ protein. At $\mathrm{pH} 4.5, \mu$ moles cystine reduced $/ 2 \mathrm{hr} / \mathrm{mg}$ protein.

intestinal mucosa. However, in view of the differences in the nature of the tissues examined and in the methodology of enzyme assay employed in these respective studies, speculation as to the basis of these contrasting results does not appear warranted at the present time.

The results of the transhydrogenase measurements carried out in this investigation indicated that there was no observable difference in the levels of enzyme activity of normal and cystinotic leukocyte whole cell extracts or granular cell fractions throughout the $\mathrm{pH}$ range of 4.5-7.5, nor in extracts of normal and cystinotic human liver at $\mathrm{pH} 4.5$ [29]. Patrick [11] had previously demonstrated normal GSH-CySSCy activity at neutral $\mathrm{pH}$ in cystinotic liver.

The pronounced accumulation of cystine within lysosomes of cystinotic leukocytes which contain an otherwise normal cytoplasmic complement of disulfidereducing activity suggests that this amino acid is unable to penetrate the lysosomal membrane either because of the lack of a specific cystine-cleaving enzyme within this organelle or because of an absent or defective transport mechanism essential for its egress to the cytoplasm. Although these alternative possibilities cannot be resolved at the present time they are in accord with the observations of Schulman and Bradley $[17,18]$ on the characteristic vacuolation undergone by cystinotic fibroblasts which have been exposed to media containing stereoisomers of cysteine-penicillamine mixed disulfide. Vacuolation was attributed to the abnormal retention of osmotically active disulfide within the lysosomal granules of such cells following endocytosis and could be correlated with a high intracellular content of the administered compound [18]. Normal cells did not appear to exhibit vacuolation under similar circumstances and contained only negligible intracellular concentrations of disulfide. In the presence of the symmetrical penicillamine disulfides, however, normal as well as cystinotic cells were observed to exhibit vacuolation. The retention of these symmetrical disulfides within normal cells suggests that they are either resistant to lysosomal cleavage or else they do not fulfill the 
specificity requirements for transport. In experiments carried out in connection with the present study it was found that penicillamine disulfide was resistant to the action of transhydrogenase of normal leukocytes whereas the mixed cysteine-penicillamine disulfides were reduced with ease. It is unlikely, however, that a meaningful correlation can be made between the observed enzymic reduction of these disulfides and the absence or formation of vacuoles in normal fibroblasts since the transhydrogenase used in this study was derived from the soluble fraction of normal leukocytes; furthermore, it is known that penicillamine disulfide is markedly resistant to chemical reductive cleavage $[1,3]$ in contrast to the mixed disulfide with cysteine.

The studies reported in this paper were initiated with the hope of finding an enzyme activity associated with reductive catabolism of cystine in lysosomes which might prove to be related to the abnormal retention of this amino acid seen in cystinosis. The failure to find such a lysosomal activity can be interpreted in a number of ways. (1) Conditions of extraction or assay were such as to result in loss or reduction of enzyme activity, either through lability of the enzyme itself or by loss or inactivation of an essential cofactor. Although these considerations warrant an extension of our experimental procedure to alternative methods of lysosomal disruption (e.g., hypotonicity, sonication, detergents), it should be noted that our use of freezethaw treatment was based upon the procedure utilized by States and Segal [26] in their demonstration of GSH-cystine transhydrogenase activity in lysosomes of rat intestinal mucosa. (2) The initial step in the lysosomal catabolism of cystine may involve mechanisms other than reduction, e.g., oxidative [10] or other degradative [4] reactions. (3) Lysosomes may be metabolically inert with respect to cystine, the basic biochemical defect in cystinosis being related solely to an abnormality in the mechanism of efflux of the amino acid through the lysosomal membrane into the cytoplasm. Further investigation will be required in order to decide between these or other alternatives.

\section{Summary}

The enzymic reduction of cystine in the supernatant and granular fractions of cultured and freshly drawn leukocytes obtained from normal and cystinotic individuals has been investigated. The only relevant activity detected in these cells, viz., a glutathione-cystine transhydrogenase activity, was found to be present almost exclusively in the high-speed $(100,000 \times g)$ su- pernatant fraction; no significant enzyme activity could be detected in the lysosome-containing fractions or other granular fractions of normal or cystinotic cells over a broad range of $\mathrm{pH}(4.5-7.5)$. No difference in the comparative levels of transhydrogenase activity in normal and cystinotic cells was apparent when measured either in whole cell extracts or in the supernatant fractions thereof. The bearing of these observations on the pathogenesis of cystinosis is discussed.

\section{References and Notes}

1. Abraham, E. P., Baker, W., Chain, E., and Robinson, R.; Chemical nature of 2-pentenylpenicillin. In: H. T. Clarke, J. R. Johnson, and R. Robinson: The Chemistry of Penicillin, p. 31. (Princeton University Press, Princeton, 1949).

2. Bikel, H., Smallwood, W. C., Smellie, J. M., and Hickmans, E. M.: Clinical description, factual analysis, prognosis and treatment of Lignac-Fanconi disease. Acta Paediat., 42 (suppl. 90): 27 (1952).

3. Boyde, T. R. C.: The reaction between cyanide and the mixed disulfide of cysteine and penicillamine. J. Chem. Soc. (C): 2751 (1968).

4. Cavallini, D., DeMarco, C., Mondovi, B., and Mori, B. G.: The cleavage of cystine by cystathionase and the transsulfuration of hypotaurine. Enzymologia, 22: 161 (1960).

5. GrRber, P., AND Monroe, J. H.: Studies on leukocytes growing in continuous culture derivied from normal human donors. $J$. Natl. Cancer Inst., 40: 855 (1968).

6. Hummeler, B. A., Zajac, B. A., Genel, M., Holtzapple, P. G., AND SEgAL, S.: Human cystinosis: intracellular deposition of cystine. Science, 168: 859 (1970).

7. LAYNE, E.: Spectrophotometric and turbidimetric methods for measuring proteins. In: S. P. Colowick and N. O. Kaplan: Methods in Enzymology, Vol. III, p. 454. (Academic Press, New York, 1957).

8. Linneweh, F., Schaumlöffel, E., Graul, E. M., Hundeshagen, H., Kirsten, E., Kirsten, R., and Barthelmai, W.: Über den Cystin-Metabolismus bei der Cystinose. Klin. Wschr., 42 : 999 (1964).

9. Mahoney, C. P., And Trump, B. F.: Studies in cystinosis. Am. J. Dis. Child., 104: 563 (1962).

10. Medes, G., AND Floyd, N.: Metabolism of sulfur. II. Further investigation of enzymic oxidation of sulfur-containing amino acids. Biochem. J., 36: 259 (1942).

11. PAtrick, A. D.: The degradative metabolism of $\mathrm{L}$-cysteine and L-cystine in vitro by liver in cystinosis. Biochem. J., 83: 248 (1962).

12. Patrick, A. D., and Lake, B. D.: Cystinosis: electron microscopic evidence of lysosomal storage of cystine in lymph node. J. Clin. Path., 21: 571 (1968).

13. RALL, T. W., AND LEHNINGER, A. L.: Glutathione reductase of animal tissues. J. Biol. Chem., 194: 119 (1952).

14. Schneider, J. A., Bradley, K. H., and Sefgmiller, J. E.: Increased cystine in leukoctes from individuals homozygous and heterozygous for cystinosis. Science, 157: 1321 (1967).

15. Schneider, J. A., Bradley, K. H., and Seegmiller, J. E.: Transport and intracellular fate of cystine ${ }^{35} \mathrm{~S}$ in leukocytes 
from normal subjects and patients with cystinosis. Pediat. Res., 2: 441 (1968).

16. Schneider, J. A., Rosenbloom, F. M., Bradley, K. H., ANd SEEGMILLER, J. E.: Increased free-cystine content of fibroblasts cultured from patients with cystinosis. Biochem. Biophys. Res. Commun., 29: 527 (1967).

17. Schulman, J. D., and Bradley, K. H.: Cystinosis: selective induction of vacuolation in fibroblasts by L-cysteine-D-penicillamine disulfide. Science, 169: 595 (1970).

18. Schulman, J. D., and Bradley, K. H.: The metabolism of amino acids, peptides, and disulfides in lysosomes of fibroblasts cultured from normal individuals and those with cystinosis. J. Exp. Med., 132: 1090 (1970).

19. Schulman, J. D., Bradley, K. H., Berezesky, I., Grimley, P., Dodson, W. E., AND Al-Aish, M.: Biochemical, morphologic and cytogenetic studies of leukocytes growing in continuous culture from normal individuals and patients with cystinosis. Pediat. Res., 5: 501 (1971).

20. Schulman, J. D., Bradley, K. H., and Seegmiller, J. E.: Cystinosis: compartmentalization within lysosomes in cystinotic leukocytes. Science, 166: 1152 (1969).

21. Schulman, J. D., Wong, V. G., Kuwabara, T., Bradley, H., and SeEgmilier, J. E.: Intracellular cystine content of leukocyte populations in cystinosis. Arch. Intern. Med., 125: 660 (1970).

22. Schulman, J. D., Wong, V. G., Olson, W. H., And Seegmiller, J. E.: Lysosomal site of crystalline deposits in cystinosis as shown by ferritin uptake. Arch. Path., 90: 259 (1970).

23. Schultz, J., Carlin, R., Odd, F., Kaminker, K., and Jones, W.: Mycloperoxidase of the leukocyte of normal human blood. IIr. Isolation of the peroxidase granule. Arch. Biochem. Biophys., 111: 73 (1965).

24. Sergmiller, J. E., Friedmann, T., Harrison, H. E., Wong, V. G., AND SCHNEIDER, J. A.: Cystinosis: combined clinical staff confcrence at the National Institutes of Health. Ann. Intern. Med., 68: 883 (1968).

25. Seegmiller, J. E., $\Lambda_{\text {ND }}$ Howell, R. R.: Cystine metabolism in DeToni-Fanconi syndrome with cystinosis. Clin. Res., 9: 189 (1961).

26. States, B., AND SEGaL, S.: Distribution of glutathione-cystine transhydrogenase in subcellular fractions of rat intestinal mucosa. Biochem. J., 113: 443 (1969).

27. TIETZE, F.: Disulfide reduction in rat liver. I. Evidence for the presence of nonspecific nucleotide-dependent disulfide reduc- tase and GSH-disulfide transhydrogenase activities in the high-speed supernatant fraction. Arch. Biochem. Biophys., 138: 177 (1970).

28. Tretze, F.: Disulfide reduction in rat liver. II. Chromatographic separation of nucleotide-dependent disulfide reductase and GSH-disulfide transhydrogenase activities of the highspeed supernatant fraction. Biochim. Biophys. Acta, 220: 449 (1970).

29. TIETZE, F.: Unpublished data.

30. Wendel, P. L.: Distribution of glutathione reductase and detection of glutathione-cystine transhydrogenase in rat tissues. Biochim. Biophys. Acta, 159: 179 (1968).

31. Wong, V. G.: Kuwabara, T., Brubaker, R., Olson, W., SchulMAN, J. D., AND SEEgmirler, J. E.: Intralysosomal cystine crystals in cystinosis. Invest. Ophthalmol., 9: 83 (1970).

32. Worthen, H. G., And Good, R. A.: The pathogenesis of cystinosis. Am. J. Dis. Child., 102: 494 (1961).

33. Nutritional Biochemicals Corporation, Cleveland, Ohio.

34. Aldrich Chemical Company, Phillipsburg, N.J.

35. Calbiochem, Los Angeles, Calif.

36. Mann Research Laboratories, New York, N.Y.

37. Packard Instrument Company, Inc., Downers Grove, Ill.

38. No. 50.1 rotor [39].

39. Model L ultracentrifuge, Beckman Instruments, Inc., Spinco Division, Palo Alto, Calif.

40. No. 39 swinging bucket rotor [39].

41. Model 14 recording spectrophotometer, Cary Instruments, Monrovia, Calif.

42. The experiments with human subjects reported in this investigation have been carried out in accordance with the provisions set forth in the Declaration of Helsinki.

43. Obtained through the cooperation of the Blood Bank of the National Institutes of Health.

44. The present address of Dr. K. H. Bradley is: National Heart and Lung Institute, National Institutes of Health, Bethesda, Maryland.

45. The present address of Dr. J. D. Schulman is: Departments of Obstetrics and Gynecology and Pediatrics, New York Hos. pital-Cornell Medical Center, New York, New York 10021.

46. Requests for reprints should be addressed to: Frank TIETzE, PH.D., National Institute of Arthritis and Metabolic Diseases, National Institutes of Health, Building 10, Room 9B-05, Bethesda, Maryland 20014 (USA).

47. Accepted for publication March 2, 1972. 